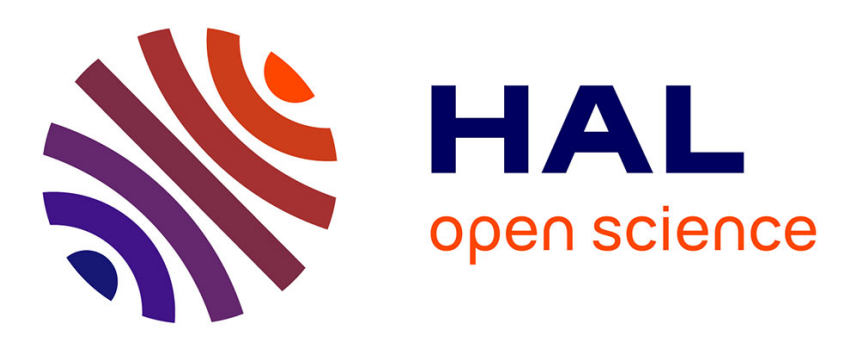

\title{
METASTABLES STRUCTURES IN LASER SURFACE MELTED ALLOYS
}

\author{
Jean Pelletier, D. Pergue
}

\section{To cite this version:}

Jean Pelletier, D. Pergue. METASTABLES STRUCTURES IN LASER SURFACE MELTED ALLOYS. Journal de Physique Colloques, 1987, 48 (C7), pp.C7-135-C7-138. 10.1051/jphyscol:1987724 . jpa-00227026

\section{HAL Id: jpa-00227026 https://hal.science/jpa-00227026}

Submitted on 1 Jan 1987

HAL is a multi-disciplinary open access archive for the deposit and dissemination of scientific research documents, whether they are published or not. The documents may come from teaching and research institutions in France or abroad, or from public or private research centers.
L'archive ouverte pluridisciplinaire HAL, est destinée au dépôt et à la diffusion de documents scientifiques de niveau recherche, publiés ou non, émanant des établissements d'enseignement et de recherche français ou étrangers, des laboratoires publics ou privés. 
METASTABLES STRUCTURES IN LASER SURFACE MELTED ALLOYS

\author{
J.M. PELLETIER and D. PERGUE \\ Groupes d'Etudes de Métallurgie Physique et de Physique des \\ Matériaux, (CNRS LA-341), INSA-LYON, Bâtiment 502, \\ F-69621 Villeurbanne Cedex, France
}

\begin{abstract}
Rapid solidification by laser annealing enables the obtention of non-equilibrium phases. Surface vitrification is obtained in alloys with a suitable composition (for example Pd-Si-Cu), but cracks are observed. Hardening microstructures are formed in low carbon steels.
\end{abstract}

\title{
INTRODUCTION
}

Laser processing uses a high power laser beam to heat a thin surface region rapidly, with the underlying bulk providing selfquenching. So rapid surface melting followed by rapid solidification at cooling rates as high as $10^{6} \mathrm{c} / \mathrm{s}$ may be obtained, and therefore metastable structure are observed (1).

Rapid solidification offers different possibilities :

- homogeneization of the material

- substantial refinement and re-morphologiying of microstructures

- solid solubility extension

- obtention of non-equilibrium phases, crystalline or amorphous.

The purpose of the present work is to illustrate this last phenomenon. Applications in view are essentially high-strength structural materials and corrosion-resistant materials.

\section{EXPERIMENTAL PROCEDURE}

Two kinds of alloys have been used :

a) bulk alloys capable of vitrification by classical rapid solidification technics

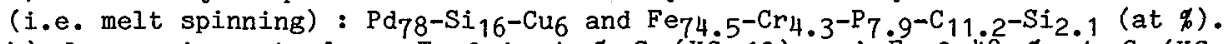

b) low carbon steels : Fe-0.1 wt $\% \mathrm{C}\left(\mathrm{XC}^{5} 10\right)$ and Fe-0.48 \% wt C (XC 48) ; microstructures observed in such alloys after classical thermal treatments are well known.

Bulk samples ( $20 \times 20 \times 8 \mathrm{~mm}^{3}$ ) were irradiated with a $\mathrm{CW} \mathrm{CO}_{2}$ laser (SPECTRA PHYSIC, $5 \mathrm{~kW}$ or CILAS CI $4000,4 \mathrm{~kW})$. Samples are moved in front of the laser beam with a speed ranging from 0.25 to $3 \mathrm{~m} / \mathrm{s}$, under argon blasting to minimize oxidation. Experiments have also been performed with a pulsated YAG laser (LASER APPLICATIONS, LAP 300) ; the on-time of pulse was $0.2-20 \mathrm{~ms}$ and the output of the laser was $300 \mathrm{~W}$. The cross-section of the specimen was observed by optical or scanning electron microscope after electrochemical etching (nital for $\mathrm{Fe}$-base alloys and aquia regia for Pd-Si-Cu).

Structure of the laser-treated surface was studied by X-ray diffraction using a copper target.

Microhardness measurements have also been carried out (load : $100 \mathrm{~g}$ ).

EXPERIMENTAL RESULTS

\section{1) Surface amorphization :}

Experiments are performed with the $\mathrm{CO}_{2}$ laser : to obtain wide treated zones, the sample was shifted $0.25 \mathrm{~mm}$ along the $\mathrm{y}$-axis after irradiation from one end to the other end of the specimen along the y-axis. For both alloys (Fe-Cr-P-C-Si and 
Pd-Si-Cu); the observations show two different zones :

- a uniform near surface region, the thickness $t$ of which decreases as the scanning speed $v$ increases : for $v=0.5 \mathrm{~m} / \mathrm{s}, t \approx 100 \mathrm{Nm}$ and for $v=2 \mathrm{~m} / \mathrm{s}$, $\mathrm{t} \approx 30 \mathrm{Nm}$ (output power : $4.7 \mathrm{~kW}$; beam diameter $\approx 1 \mathrm{~mm}$ ).

- the substrate not affected by the treatment; its structure is typical of an eutectic of hypereutectic alloy.

No heat affected zone is observed. Cracks are formed either in the melted zone or around this treated region. The crack formation is due to contraction restricted by the underlying solid during solidification and to the fact that hard and brittle phase mixtures of phosphide, carbide and others are formed.

Fig. 1 and 2 show $X-r a y$ diffraction patterns of laser-treated alloys ; characteristic crystalline peaks are observed on the substrate : their intensity decreases as the scanning speed increases (and therefore as the irradiation duration decreases) and for high $v$ values only a broad peak is present, typical of amorphous phase. This result may be explained by the increase of quenching rate accompaning the speed increase.

However two remarks may be done :

- the vanishing of X-ray peaks is more pronounced in the Pd-Si-Cu alloy than in the Fe-base alloy; this feature is related to the greater glass forming ability of the first material, in agreement with previous results $(2,3)$.

- the absence of X-ray diffraction peak don't imply a perfect vitrification. In effect a companion study (4) performed by transmission electron microscopy in the same Fe-Cr-P-C-Si alloy indicates that the solidification structure is rather complex and that amorphisation is not complete.

A perfect vitrification has been obtained on the same alloy by using ultra short laser pulses (duration : only a few nanoseconds (5)) ; but in such conditions the thickness of the melted zone is very small, since it don't exceed a few hundreds of nanometers.

\section{2) Hardening in a low-carbon steel by laser metling :}

The observation of cross-sections of laser-melted low-carbon steels shows three different zones ( $f i g, 3$ ).

- a near surface region, melted during the treatment ; the microstructure is of martensitic type.

- a heat affected zone (HAZ), in which a substantial grain refinement is observed; the pearlite dissolution is not fully achieved, as show by scanning electron microscopy.

- the substrate not affected by the treatment : a mixture of ferrite of pearlite.

Some results of hardness measurements are summarized in table I :

$\begin{array}{lccccc}\text { Alloy } & \begin{array}{c}\text { irradiation } \\ \text { duration }\end{array} & \begin{array}{c}\text { power } \\ \text { density }\end{array} & \begin{array}{c}\text { substrate } \\ \text { hardness }\end{array} & \begin{array}{c}\text { H A Z } \\ \text { hardness }\end{array} & \begin{array}{c}\text { Melted zone } \\ \text { hardness }\end{array} \\ \text { XC } 10 & 10 \mathrm{~ms} & 5.10^{5} \mathrm{~W} / \mathrm{cm}^{2} & 180 & 350 & 400 \\ \text { XC } 48 & 10 \mathrm{~ms} & 5.105 \mathrm{~W} / \mathrm{cm}^{2} & 220 & 660 & 780\end{array}$

Table I : Vickers hardness corresponding to various microstructural states.

In the melted zone hardening is due to the existence of a non-equilibrium phase ; i.e. the martensitic phase ; in the HAZ the grain refinement induces the hardness increase (fig. 3). If it is well known (and for a long time !) that quenching improves the mechanical properties of steels, laser treatment confirms and strengthens this results, owing to the large quenching rates induced by such treatments.

\section{DISCUSSION}

Observed phenomena are related to rapid solidification processes. Crystallization occurs only if crystal growth velocity in higher than isotherm speed (6). In pure metals only simple collision of liquid atoms with the crystal surface is required 
for crystallization and therefore vitrification is never observed. In alloys crystal growth is diffusion-limited, since changes in composition are required and consequently glass-formation is easier. In laser treatments the heat transfert between the melted material and the substrate is very good and therefore high quenching rates (i.e. high isotherm speed) are obtained.

In Fe-Cr-P-C-Si alloys a quenching rate of about $10^{6} \mathrm{k} / \mathrm{s}$ provides the vitrification of the alloy by melt-spinning (7). In order to estimate this quenching rate in the present experimental conditions, calculations have been performed, using the numerical heat transfer model proposed by Jain et al (8). With the following parameter values : irradiation duration : $2 \mathrm{~ms}$, energy density : $4.2 .10^{5} \mathrm{~J} / \mathrm{cm}^{2}$ and with the values of physical data given by Ashby et al (9), the results are as followed :

- the thickness of the melted zone will be about $100 \mathrm{~m}$ and those of the HAZ $\left(T>900^{\circ} \mathrm{C}\right)$ will be of the same magnitude.

- quenching rates values will reach $10^{6} \mathrm{~K} / \mathrm{s}$ during of the solidification process.

This model is very rough, since temperature is assumed to remain constant during the solidification $\left(T=T_{m}\right)$; however surface vitrification (at least a partial vitrification) may be correctly predicted and the thickness of the treated region is also in agreement with experimental observations.

Solid state transformations occuring in the HAZ of a laser treated low carbon steel are due to carbon diffusion phenomena ; assuming that cementite and pearlite plates are distant from, pearlite dissolution requires a diffusion of carbon atoms along a distance $\lambda$ and the time $t$ for such a dissolution is given by (9) :

$\lambda^{2}=2 \mathrm{D} t \mathrm{for}$ an isothermal treatment ; for a more complexe thermal cycle $\lambda^{2}=\int_{0}^{\infty} D_{0} \exp (-Q / R T(t)) d t \approx 2 D_{0} \alpha \tau \exp \left(-Q / R T_{p}\right)$

with : $Q_{0}$ : apparent activation energy for the transformation

$\mathrm{R}$ : gaz constant

$\mathrm{T}_{\mathrm{p}}$ : maximum temperature reached during thermal cycle

$\alpha, \tau$ : constants ; their expression depends on irradiation time.

With the values proposed by Ashby et al (9), the distance an atom can diffuse during laser treatment is much lower than $10 \mathrm{~N}$ m for irradiation times in the millisecond range ; therefore pearlite dissolution cannot be achieved in the HAZ, in agreement with present observation in the Fe-0.1 wt \% C alloy.

\section{CONCLUSION}

Two kinds of metastables structures in laser surface melted alloys have been presently studied :

- surface vitrification of alloys whose compositions were suitable for the formation of amorphous phases (Pd-Si-Cu and Fe-Cr-P-C-Si) ; X-ray diffraction patterns exhibit features typical of amorphous phase ; but cracks are observed and vitrification may be not complete.

- hardening microstructures in low carbon steels; large hardness increases are effectively observed.

In both situations, laser treatment enables high quenching rate values required for the freezing of high temperature microstructures.

\section{REFERENCES}

(1) N. BLOEMBERGEN, in "Laser-solid interactions and laser processings", ed. S.D. FERRIS, H.J. LEAMY and J.M. POATE, Academic Press, New-York, 1 (1979).

(2) H. YOSHIOKA, K. ASAMI et K. HASHIMOTO, Scripta Metall., 18, 1214 (1984).

(3) K. ASAMI, T. SATO et K. HASHIMOTO, J. Non Cryst. Solids, 68, 261 (1984).

(4) E. GAFFET, G. DELUZE, G. MARTIN and J.M. PELLETIER, This Conference.

(5) J.C. LIN, F. SPEAPEN and D. TURNBULL, J. Non Cryst. Solids, 61-62, 767 (1984).

(6) F. SPAEPEN and C.J. LIN, MRS, Strasbourg, 5-8 June (1984), p. 65.

(7) H. DAVIES, RQM III, BRIGHTON (1983).

(8) A.K. JAIN, V.N. KULKARI é D.K. SOOD, Appl. Phys., 25, 127 (1979).

(9) M.F. ASHBY et K.E. EASTERLING, Acta Metall., 32, 1935 (1984). 


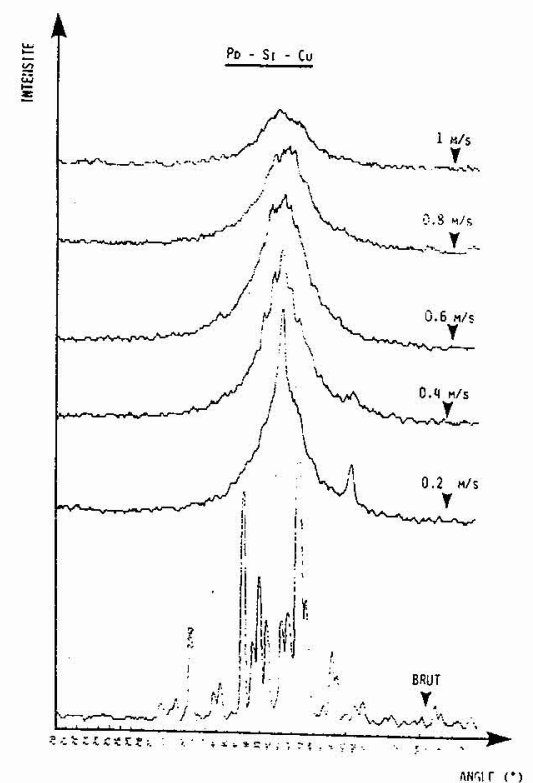

Fig. 1 - X-ray diffraction patterns of $\mathrm{Pd}-\mathrm{Si}-\mathrm{Cu}$ alloy after laser surface treatement with specimen speed ranging from $0.2 \mathrm{~m} / \mathrm{s}$ up to $1 \mathrm{~m} / \mathrm{s}$; output power : $3 \mathrm{KW}$; beam diameter : $1 \mathrm{~mm}$.

Fig. 2 - X-ray diffraction patterns of $\mathrm{Fe}-\mathrm{Cr}-\mathrm{P}-\mathrm{C}-\mathrm{Si}$ alloy after laser surface treatment with specimen speed ranging from 0.5 to $2 \mathrm{~m} / \mathrm{s}$; output power : $4.7 \mathrm{~kW}$; beam diameter : $1 \mathrm{~mm}$.
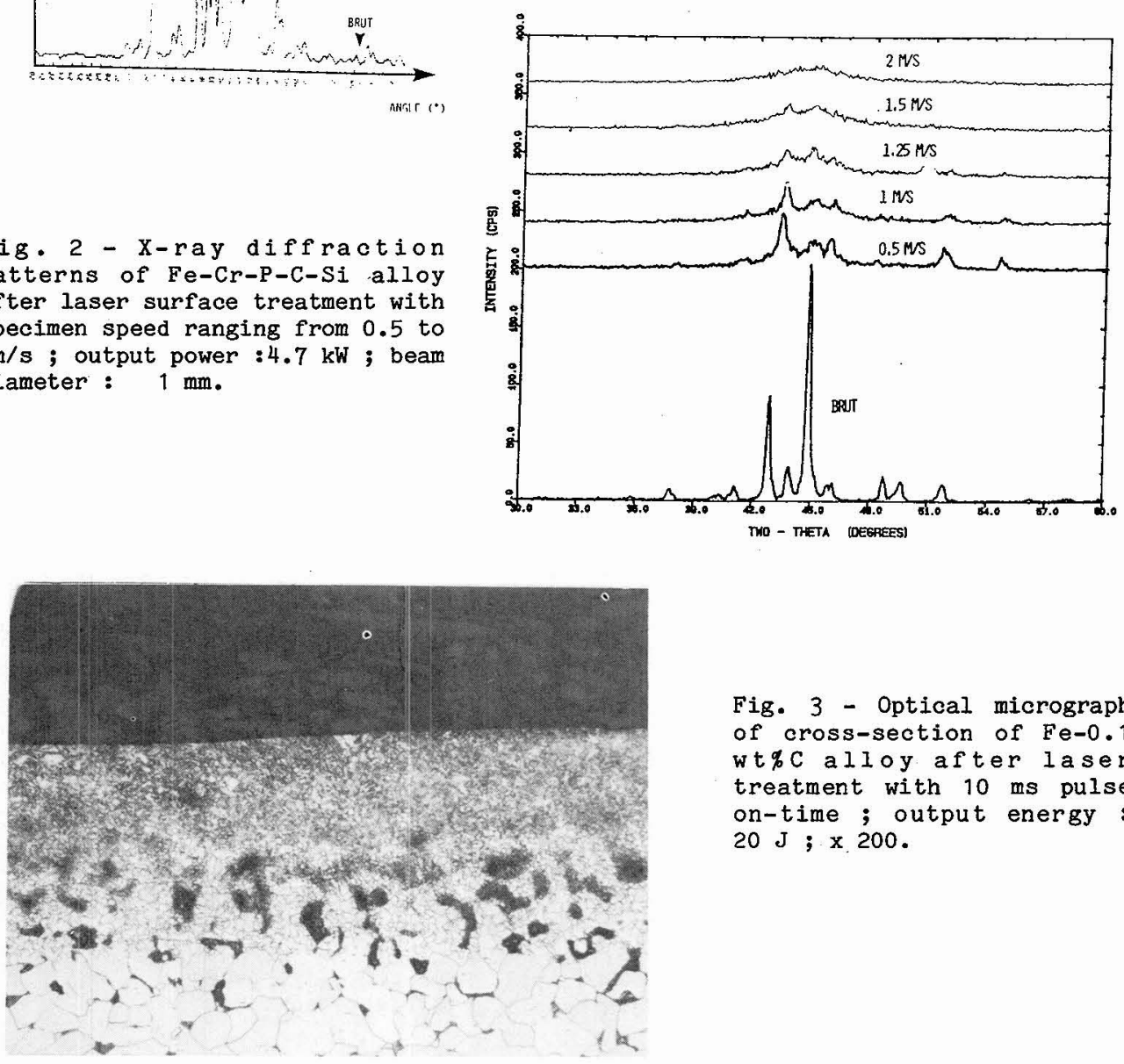

Fig. 3 - Optical micrograph of cross-section of $\mathrm{Fe}-0.1$ wt\%c alloy after laser treatment with $10 \mathrm{~ms}$ pulse on-time; output energy : $20 \mathrm{~J} ; \times 200$. 